James M. Saslow. The Poetry of Michelangelo: An Annotated Translation. New Haven and London: Yale UP, 1991. Pp. xiv, 559.

This volume serves well those who are unfamiliar with Michelangelo's poetry, those who have read the poems in the original Italian, as well as scholars. Along with translations into English of the entire corpus of Michelangelo's poetry, it contains a cogent introductory essay by Saslow, a concordance to the editions in Italian and translations in English of Michelangelo's verse, a concordance to his drawings and an extensive bibliography that includes the Florentine's writings along with the traditionally most important and most recent secondary sources. Among the illustrations included in this edition are reproductions of works of figurative art that are placed in proximity to contemporaneous works of poetry and reproductions of folios on which original drawings and poetic texts appear together. Thus the novice can begin to appreciate this important yet less well-known aspect of Michelangelo's creative life while those who are already familiar with his poetry will find this volume a useful reference work.

As Saslow states in the essay that precedes the poems, his purpose in compiling this edition is "to provide a broad general introduction to Michelangelo's life and the functions that poetry served in it." This is to be accomplished through "a clear and faithful rendering of Michelangelo's words; factual information ... and textual commentary" (6). Not only has Saslow accomplished this goal, but his decision to privilege in the translations Michelangelo's diction and phrasing over rhythmical considerations allows the reader to follow the complex nature of the internal and spiritual torment that gave rise, in many of the compositions, to poetic expression. Saslow, in both his commentary and translations shows an acute sensibility to the nuances of Michelangelo's difficult language and syntax. The annotation helps make clearer a poetic voice that, indeed, to use Saslow's phrasing, "is so often archaic, obscure, or elliptical that many editors from Guasti to Girardi have felt it necessary to provide prose paraphrases as well as line-by-line annotations" (57). In addition, Saslow's desire to render the original faithfully is underscored by the juxtaposition of the original texts, which, in turn, serve neither as pretext nor as poetic inspiration for the translator. Thus, the ideas that inform the original compositions remain a vital element of the translations.

This is consistent with what Saslow affirms in the introductory essay. In his view, Buonarroti's poems are not to be considered merely as an exegetical tool whose function it is to enhance appreciation of the Florentine's figurative art. In fact, the poems must be considered an autonomous part of a dialectic totality. At the same time, they must be evaluated on their own artistic merit or lack thereof. Consequently, Michelangelo's verse must be seen at once against the backdrop provided by his personal and artistic biographies and within the historical, social and cultural milieu of which it was a part. Saslow collates and summarizes previous critical opinion to which he adds his own views regarding Michelangelo's sexuality. His periodization of Michelangelo's poetic oeuvre, based on thematic considerations, the persona's interlocutor within the broader social and political framework of the Cinquecento, is sound. Buonarroti's refusal of the Petrarchan tradition that dominated Italian literary thought during the first half of the sixteenth century is highly significant and, as Saslow indicates, underpinned the artist's "deliberate attempt to find a distinctive if idiosyncratic voice" (6). Michelangelo's verse became increasingly directed toward spiritual concerns during the last several decades of his life due to the friendship of 
Vittoria Colonna on the one hand and the restoration of the Medici in Florence on the other. This progression comes to the fore here not only through the translator's adherence to the original text; it is also underscored by the commentary and by illustrations that allow the reader to go beyond the confines of a specific creative medium and see more clearly the relation between Michelangelo's poetry and his figurative art.

\section{JOSEPH FRANCESE}

Michigan State University

Pietro Aretino. L'Orazia. Edizione critica a cura di Michael Lettieri. Con un saggio sulla storia della critica e una nota bibliografica di Rocco Mario Morano. Rovito (Cosenza): Marra Editore, 1991. Pp. cccxix, 232.

Il bisogno di una nuova edizione critica dell'Orazia nasce dal dilemma editoriale posto dalle due giolitine in esistenza: l'originale del 1546 (V46) e quella del 1549 (V49), stampata, con ritocchi, forse dallo stesso Aretino, ma con poca cura e parecchie aberrazioni. Le varianti e le corruzioni cui diedero luogo i due esemplari continuarono a propagarsi fino al nostro secolo, anche se recentemente si sono fatti grandi sforzi filologici (Ferrero, 1970) per fissare un testo definitivo. La situazione sembrava che si fosse polarizzata agli inizi del settanta tra l'edizione del Ferrero (1970), che si fonda sulla seconda cinquecentina, e quella del Petrocchi (1971) esemplata sulla princeps. A giudicare da ulteriori eventi editoriali sembra che sia infine prevalso il testo criticamente accertato dal Petrocchi, riprodotto con pochi interventi dal Pinchera (1974), dall'Ariani (1977), e ultimamente da Renzo Cremante (1988). Ma anche qui Michael Lettieri avverte lacune da colmare, e inconsistenze da emendare.

Con questo volume ponderoso Lettieri riesce pienamente nel suo scopo di correggere una situazione editoriale che il Pinchera aveva già definito "incerta e lacunosa" (cclvii). L'intento di compiutezza e di freschezza di informazioni con cui il Lettieri promette di fissare in forma definitiva il testo dell'Orazia è subito evidenziato dalla quantità e dalla densità delle note critiche. Ad esempio, la breve "Premessa" è corredata da 27 note che si spiegano lungo quattro fitte pagine del volume. Compiutezza e ricchezza di informazioni bibliografiche, storiche e critiche sono anche alla base dell'ampio saggio introduttivo di Rocco Morano che passa in rassegna secoli di critica letteraria sull'Aretino, e sull'Orazia. Per semplificare il discorso che per la sua massima esaustività potrebbe risultare piuttosto intricato, Morano scavalca ogni barriera cronologica e raggruppa l'ingente mole della critica tra negativa, positiva e "mediana". Va fatto osservare che non si tratta solo di una rassegna elencatoria, ché il Morano sa dare con agilità intellettuale una lucida prospettiva storica e comparativa discutendo e paragonando contributi critici italiani e stranieri. La sua vasta conoscenza della critica aretiniana francese, spagnola, inglese e tedesca gli consente di portare avanti un discorso chiaro, compendioso e completo sì da offrire una visione panoramica del pensiero critico che sin dal '500 si è andato sviluppando sia in Italia che all'estero sull'Orazia di Pietro Aretino. Anche qui l'intento di compiutezza è evidenziato dal vasto respiro del saggio (xxi-lxxxiii) provvisto di 241 note che occupano ben 156 pagine (lxxxiv-ccxxxix). Conclude il contributo del Morano una ricca Nota bibliografica che fornisce, in ordine cronologico, dati bibliografici anche di testi non discussi nel saggio o nelle note. 